\title{
Helicobacter pylori HAS NO INFLUENCE ON DISTAL GASTRIC CANCER SURVIVAL
}

\author{
Renata S. SANTOS ${ }^{1}$, José E. V. LOURENÇO ${ }^{1}$, Fernando Augusto Mardiros HERBELLA ${ }^{1}$, \\ Jose Carlos Del GRANDE ${ }^{1}$ and Marco G. PATTI
}

\begin{abstract}
Context - There is some evidence that Helicobacter pylori correlates with distal gastric cancer genesis. However, few studies analyzed the survival related to H. pylori infection. Objective - To correlate gastric cancer survival and H. pylori infection. Methods - Sixty-eight patients with distal gastric cancer that underwent subtotal gastrectomy were studied. Minimal follow-up was 1 month. H. pylori infection was confirmed by biopsy. Results - Thirty-four patients (19 males (55.9\%), mean age 60.9 \pm 14.03 , range 33-82 years) were $H$. pylori positive. Thirty-four patients (16 males (47.1\%), mean age 57.9 \pm 13.97 , range 27-85 years) were $H$. pylori negative. Groups were comparable in regards to age $(P=0.4)$, gender $(P=0.5)$, stage $[\mathrm{T}(P=0.2), \mathrm{N}(P=0.6)$ and $\mathrm{M}(P=0.9)]$. Survival was not different when groups were compared $[P=0.1616$ (hazard ratio $0.6834,95 \%$ CI 0.4009 to 1.1647 ) $]$. Conclusions $-H$. pylori infection does not affect distal gastric cancer survival.
\end{abstract}

HEADINGS - Stomach neoplasms. Helicobacter infections.

\section{INTRODUCTION}

Gastric cancer survival is low, especially in the West, not exceeding $25 \%$ at 5 years ${ }^{(2)}$. The prognosis after treatment is linked to classic oncologic factors such as tumor histology, stage, macroscopic characteristics, etc. ${ }^{(2,3)}$. There is strong evidence that Helicobacter pylori (HP) is associated to gastric adenocarcinoma genesis ${ }^{(2,7)}$; however, few studies have analyzed survival related to HP infection $^{(4,5,6,8)}$.

This study aims to analyze HP infection as a prognostic factor for survival in patients with distal gastric adenocarcinoma.

\section{METHODS}

Sixty-eight patients with stomach adenocarcinoma originated in the gastric antrum submitted to surgical therapy were retrospectively studied.

Patients were grouped according to the presence of HP infection detected by endoscopic biopsy and histological analysis prior to the operation. Samples were collected from normal mucosa at the antrum. HP strains were not determined.
All patients underwent an open subtotal gastrectomy + DII lymphadenectomy with curative intent (R0 resection). Tumor stage were as follows, T1 - $20(29 \%)$, T2 - $19(28 \%), \mathrm{T} 3-27(40 \%), \mathrm{T} 4-2(3 \%) ; \mathrm{N} 0-28$ (41\%), N1 - $29(43 \%)$, N3 - 11 (16\%); M0 100\%.

Patients were followed-up with an upper digestive endoscopy and computerized tomography scan every 6 months until 5 years after the operation and yearly thereafter. Mean time of follow-up was $65.6 \pm 53.2$ months (range 6.7-207.3 months).

Logrank test, Student's $t$ test, Fisher's test, and Mann's Whitney test were used as indicated. $P<0.05$ was considered significant.

\section{RESULTS}

HP infection was detected in 34 patients, comprising 19 males $(55.9 \%)$, with a mean age of $60.9 \pm 14.03$ years (range 33-82 years).

HP infection was not detected in 34 patients, comprising 16 males (47.1\%), 16 males (47.1\%), with a mean age of $57.9 \pm 13.97$ years (range 27-85 years).

Groups were comparable in regards to age $(P=$ $0.4)$, gender $(P=0.5)$, stage [T $(P=0.2), \mathrm{N}(P=0.6)$ and $\mathrm{M}(P=0.9)]$ and time of follow-up $(P=0.9)$.

\footnotetext{
Poster presentation, Digestive Disease Week (DDW), May 1-5, 2010, New Orleans, USA

Author's contribution: RSS: acquisition of data, analysis and interpretation of data, drafting the article, final approval of the version to be published; JEVL: acquisition of data, analysis and interpretation of data, drafting the article, final approval of the version to be published; FAMH: conception and design, acquisition of data, analysis and interpretation of data, drafting the article, final approval of the version to be published; JCDG: review for intellectual content, final approval of the version to be published. ${ }^{1}$ Department of Surgery, Escola Paulista de Medicina, Federal University of Sao Paulo, Sao Paulo, Brazil; ${ }^{2}$ Department of Surgery, University of Chicago, Chicago, USA. Correspondence: Dr. Fernando A. M. Herbella - Hospital São Paulo - Surgical Gastroenterology - Division of Esophagus and Stomach - Rua Diogo de Faria, 1087, cj. 301-04037-003 - São Paulo, SP, Brasil. E-mail: herbella.dcir@epm.br
} 
Survival was not different when groups were compared $[P=0.1616$ (hazard ratio $0.6834,95 \%$ CI 0.4009 to 1.1647$)]$ (Figure 1).

\section{DISCUSSION}

Our results show that HP infection does not correlate with distal gastric cancer survival.

HP is associated to distal gastric cancer genesis ${ }^{(2)}$. The mechanism of action for the carcinogenesis is not yet fully understood. Apparently, HP infection protects against proximal gastric cancer that seems to be more related to gastroesophageal reflux disease ${ }^{(2)}$. Few studies focused on the association between HP and gastric cancer survival, but all of them appointed for better survival in HP positive patients (Figure 2). These studies did not restrict analyzes to distal tumors. Our study was entirely focused on distal tumors and no difference was noted in survival according to HP status.

We hypothesized that HP might affect the biological behavior of gastric cancer. Several mechanisms were postulated to explain HP-related carcinogenesis and possible mechanisms for different survival, such as micro satellite instability, gene mutations, regulation of matrix proteins, etc. ${ }^{(7,11)}$. Some authors found more aggressive tumors in HP negative patients ${ }^{(6,10)}$ while for others ${ }^{(5,8)}$ and in our study the number of patients with and without HP infection, tumor characteristics and population data were comparable showing a similar behavior.

Countries with high incidence of gastric cancer rates have typically a high prevalence of HP infection ${ }^{(2,7)}$. This study was conducted in an area with high prevalence of HP infection, around $65 \% \%^{(9)}$. Interestingly, other series showed a higher prevalence of HP infection and gastric cancer compared to our patients (Figure 1) and other series of gastric cancer in Brazil( ${ }^{(1)}$. Differences in HP strains may explain this finding and the lack of difference in survival found in our series. In fact, some African countries show a low gastric cancer rate but a high HP prevalence, known as the "African enigma" (7).

In conclusion, our series did not show differences in survival according to HP infection. Future studies must be conducted with HP strains identification.

\begin{tabular}{|c|c|c|c|c|c|}
\hline Author/ year & Study design & $\mathrm{n}$ & H. pylori detection & Survival & Notes \\
\hline $\begin{array}{l}\text { Meimarakis } \\
\text { et al. } 2006^{(4)}\end{array}$ & Prospective & $125 \mathrm{HP}+41 \mathrm{HP}-$ & $\begin{array}{l}\text { Bacteriological culture, serological } \\
\text { analyses and histological analyses }\end{array}$ & Better for $\mathrm{HP}+$ & All gastric locations \\
\hline Lee et al. $1995^{(5)}$ & Retrospective & $82 \mathrm{HP}+46 \mathrm{HP}-$ & & Better for $\mathrm{HP}+$ & $\begin{array}{l}\text { All gastric locations. Result not } \\
\text { confirmed by multivariated analyses }\end{array}$ \\
\hline Marreli et al. $2009^{(6)}$ & Retrospective & $256 \mathrm{HP}+41 \mathrm{HP}-$ & $\begin{array}{l}\text { Polymerase chain reaction (PCR) } \\
\text { analysis for the vacA gene in } \\
\text { gastric mucosa and serological }\end{array}$ & Better for $\mathrm{HP}+$ & All gastric locations \\
\hline $\begin{array}{l}\text { Kurtenkov } \\
\text { et al. } 2003^{(7)}\end{array}$ & Retrospective & $58 \mathrm{HP}+27 \mathrm{HP}-$ & Serological & Better for $\mathrm{HP}+$ & All gastric locations. Stage 1 only \\
\hline
\end{tabular}

FIGURE 1. Literature

$\mathrm{HP}+:$ H. pylori infection detected

$\mathrm{HP}-$ : H. pylori infection not detected

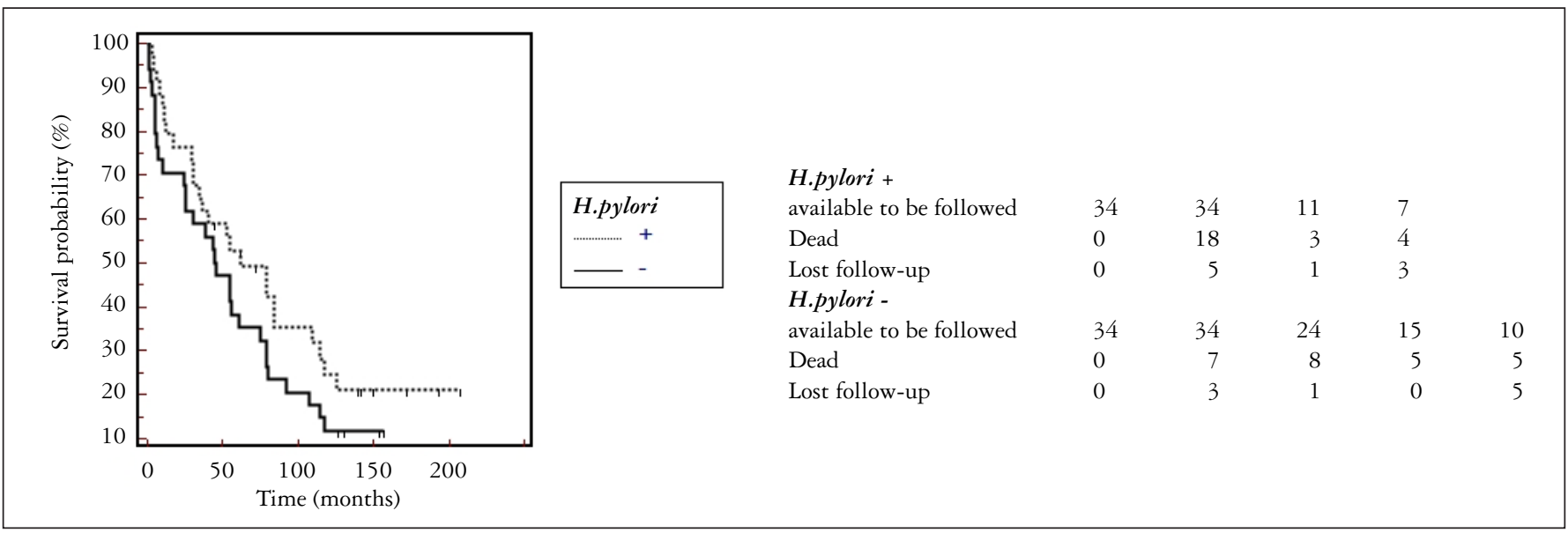

FIGURE 2. Actuarial distal gastric cancer survival in patients with and without $H$. pylori infection 
Santos RS, Lourenço JEV, Herbella FAM, Del Grande JC, Patti MG. A infecção por Helicobacter pylori não influencia a sobrevida no câncer gástrico distal. Arq Gastroenterol. 2011;48(2):109-11.

RESUMO - Contexto - Há evidência que a infecção por Helicobacter pylori correlacione-se com a etiologia do câncer gástrico distal. Há, entretanto, poucos estudos que analisam a sobrevivência relacionada ao H. pylori. Objetivo - Correlacionar a sobrevida do câncer gástrico distal com a infecção por H. pylori. Métodos - Sessenta e oito pacientes com câncer gástrico distal submetidos a gastrectomia subtotal foram estudados. O tempo mínimo de seguimento foi de 1 mês. A infecção por H. pylori foi confirmada por biopsia. Resultados - Trinta e quatro pacientes (19 homens (55,9\%), idade média de 60,9 $\pm 14,03$, variação 33-82 anos) tinham confirmação de infecção por $H$. pylori. Trinta e quatro pacientes (16 homens (47,1\%), idade média de 57,9 $\pm 13,97$, variação 27-85 anos) eram $H$. pylori negativo. Os grupos eram comparáveis considerando idade $(P=0.4)$, gênero $(P=0.5)$ e estágio [T $(P=0.2), \mathrm{N}(P=0.6)$ e M $(P=0.9)]$. Sobrevivência não foi diferente quando os grupos foram comparados $(P=0.1616$ (Hazard ratio $0.6834,95 \%$ CI 0.4009-1.1647)). Conclusão - Infecção por Helicobacter pylori não afeta a sobrevida no câncer gástrico distal.

DESCRITORES - Neoplasias gástricas. Infecções por helicobacter.

\section{REFERENCES}

1. Araújo-Filho I, Brandão-Neto J, Pinheiro LA, Azevedo IM, Freire FH, Medeiros AC. Prevalence of Helicobacter pylori infection in advanced gastric carcinoma. Arq Gastroenterol. 2006;43:288-92.

2. Catalano V, Labianca R, Beretta GD, Gatta G, de Braud F, Van Cutsem E. Gastric cancer. Crit Rev Oncol Hematol. 2009;71:127-64.

3. Dicken BJ, Bigam DL, Cass C, Mackey JR, Joy AA, Hamilton SM. Gastric adenocarcinoma: review and considerations for future directions. Ann Surg. 2005;241: 27-39

4. Kurtenkov O, Klaamas K, Sergeyev B, Chuzmarov V, Miljukhina L, Shljapnikova L. Better survival of Helicobacter pylori infected patients with early gastric cancer is related to a higher level of Thomsen-Friedenreich antigen-specific antibodies. Immunol Invest. 2003;32:83-93.

5. Lee WJ, Lin JT, Shun CT, Lee WC, Yu SC, Lee PH, Chang KJ, Wei TC, Chen KM. Comparison between resectable gastric adenocarcinomas seropositive and seronegative for Helicobacter pylori. Br J Surg. 1995;82:802-5.

6. Marrelli D, Pedrazzani C, Berardi A, Corso G, Neri A, Garosi L, Vindigni C, Santucci A, Figura N, Roviello F. Negative Helicobacter pylori status is associated with poor prognosis in patients with gastric cancer. Cancer. 2009;115:2071-80
7. Marshall BJ, Windsor HM. The relation of Helicobacter pylori to gastric adenocarcinoma and lymphoma: pathophysiology, epidemiology, screening, clinical presentation, treatment, and prevention. Med Clin North Am. 2005;89:313-44.

8. Meimarakis G, Winter H, Assmann I, Kopp R, Lehn N, Kist M, Stolte M, Jauch KW, Hatz RA. Helicobacter pylori as a prognostic indicator after curative resection of gastric carcinoma: a prospective study. Lancet Oncol. 2006;7:211-22.

9. Santos IS, Boccio J, Santos AS, Valle NC, Halal CS, Bachilli MC, Lopes RD Prevalence of Helicobacter pylori infection and associated factors among adults in Southern Brazil: a population-based cross-sectional study. BMC Public Health. 2005;5:118.

10. Wu MS, Hung HW, Wang JT, Tseng CC, Shun CT, Wang HP, Lee WJ, Lin JT. Helicobacter pylori-seronegative gastric carcinoma: a subset of gastric carcinoma with distinct clinicopathologic features. Hepatogastroenterology. 1998;45:2432-6.

11. Yeh YC, Sheu BS, Cheng HC, Wang YL, Yang HB, Wu JJ. Elevated serum matrix metalloproteinase- 3 and -7 in $\mathrm{H}$. pylori-related gastric cancer can be biomarkers correlating with a poor survival. Dig Dis Sci. 2009;55:1649-57.

Received 8/9/2010 Accepted 15/12/2010. 